\title{
Genetic Diversity Analysis Based on SSR Markers in Daffodils (Narcissus)
}

\author{
S.I. Rehman ${ }^{1}$, M.Q. Sheikh ${ }^{1}$, Z.A. Bhat ${ }^{1}$ and M.H. Khan ${ }^{2 *}$ \\ ${ }^{1}$ Division of Floriculture, S.K. University of Agricultural Sciences and Technology of \\ Kashmir, Shalimar Srinagar (J\&K), India \\ ${ }^{2}$ Division of Genetics and Plant Breeding, S.K. University of Agricultural Sciences and \\ Technology of Kashmir, Shalimar Srinagar (J\&K), India \\ *Corresponding author
}

A B S T R A C T

Keywords

Narcissus spp.,

SSR,

heterozygosity, polymorphic loci

Article Info

Accepted:

18 April 2019

Available Online:

10 May 2019
Daffodil (Narcissus spp.) belongs to family Amaryllidaceae and is a bulbous perennial grown for attractive flower, borne in spring sometimes autumn or winter. The present study was carried out to assess the genetic diversity present in daffodils in temperate region of Kashmir India using eleven sample sequence repeats (SSR's). Twenty seven genotypes of daffodils belonging to different species such as Narcissus incomparabilis, Narcissus pseudonarcissus, Narcissus jonquilla, Narcissus poeticus, Narcissus papyraceus were evaluated for molecular characterization. Microsatellite markers revealed a high level of polymorphism and Jaccord's Similarity coefficient ranged from 0.05 to 0.98 . Analysis of molecular variance (AMOVA) revealed high level of variability of 94.89 per cent within population. Whereas among population variability is 5.11 per cent. The expected heterozygosity was shown highest $(0.73)$ by marker $\mathrm{A}_{131}$ in Narcissus incomparibilis and total heterozygosity across different specieswas shown highest $(0.71)$ by marker $A_{5}$. The mean expected heterozygosity was shown highest $(0.43)$ by Narcissus incomparabilis followed by Narcissus pseudonarcissus which revealed mean expected hytrozygosity of 0.37. The locus $\mathrm{A}_{109}$ and $\mathrm{B}_{112}$ revealed highest effective alleles of 10 each, followed by $\mathrm{A}_{5}$ and $\mathrm{B}_{104}$ recording effective alleles of 9 and 8 respectively.

\section{Introduction}

Daffodils (Narcissus spp.) are bulbous perennials in the Amaryllidaceae family. Various common names including daffodil, Narcissus and Jonquil are used to describe all or some members of genus Narcissus but the daffodil is now commonly used name for all the varieties of spring flowering bulbs in the genus Narcissus (Brickell, 1996; Spaulding and Barger, 2014). The number of distinct species varies widely depending on how they are classified, while according to Straley and Utech (2002) there are about 26 species, while other workers define more than 60 species (Brickell, 1996; Ji and Meerow, 2000). Flowers are either solitary or in clusters of 2 or more, borne in spring sometimes autumn or winter. Leafless stems bear flowers each with 6 spreading perianth segments (petals), surrounding a corona which is also called as floral cup, tube or crown. The flowers are usually yellow or white occasionally green (Spaulding and Barger, 2014). The leaves are basal, often strap-shaped or cylindrical; $15-75 \mathrm{~cm}$ long depending on the species (Brickell, 1996). The daffodils are mainly divided into three 
main groups based on the length or size of the crown or cup in the perianth.

The true daffodils are trumpets, those with the crown equaling or surpassing perianth segments in length e.g. Narcissus pseudonarcissus.

Star-Narcissi or challice flower with crown about half the length of the segment e.g. N.incompariblis, $N$. triandrus.

The true Narcissi, in which the crown is very short or reduced to a rim, as $N$. poeticus, $N$. jonquilla and $N$. tazetta.

While prominent species types from the horticultural point of view are $N$. pseudonarcissus, $N$. tazetta, $N$. jonquilla and $N$. poeticus (Spaulding and Barger, 2014).

The genus Narcissus is well known for its diversity due to the vast amount of within and among species floral variation (Perez-Barrales et al., 2006). The analysis of genetic diversity and relatedness between or within different populations, species and individuals is a central task for many disciplines of biological science and classical strategies for the evaluation of genetic variability, have increasingly been complemented by molecular techniques (Weising et al., 2005).

Advances in molecular biology have allowed the development of rapid, sensitive and specific screening methods to study genetic diversity and relatedness between individuals. Simple Sequence Repeats (SSR) which is molecular technique which has been used to characterise variability in Narcissus (Simon et al., 2010), has also been used in the present study. SSR or Microsatellites consist of tandemly reiterated, short DNA sequence motifs. They frequently are size-polymorphic in a population due to a variable number of tandem repeats and these are ubiquitous components of all Eukaryotic genomes (Field and Wills, 1996; Gur-Arie et al., 2000 and Van Belkum et al., 1998).

\section{Materials and Methods}

The experimental material for the the present study comprised of (27) diverse genotypes of daffodils selected from the germplasm maintained at Division of Floriculture and Landscape Architecture SKUAST-Kashmir. The molecular analysis of the germplasm was carried out at the Division of molecular laboratory of Division of Plant Pathology. The genomic DNA was extracted from individual plant using CTAB procedure (CetylTrimthyl Ammonium Bromide) as modified by Maroof et al., (1984). The quantity of DNA was checked by Agarose gel electrophoresis. The 11 micro satellite SSR markers where used which are enlisted below (Table 1).

The available primers were used for detecting the polymorphism within the germplasm lines. The PCR amplification was carried out in $0.2 \mathrm{ml} \mathrm{PCR}$-tubes with $25 \mu \mathrm{l}$ reaction mixture. PCR amplification was performed using Thermal cycle (Whatman Biometra, TGradient, Goettingen Germany) programmed for initial $5 \mathrm{~min}$. denaturation at $94^{\circ} \mathrm{C}, 27$ cycles at $94^{\circ} \mathrm{C}$ for 30 seconds, annealing at $67-43^{\circ} \mathrm{C}$ for 30 seconds, 17 cycles at $94^{\circ} \mathrm{C}$ for 30 seconds, $53^{\circ} \mathrm{C}$ for 30 seconds, $72^{\circ} \mathrm{C}$ for 30 seconds and a final extension at $72^{\circ} \mathrm{C}$ for 10 minutes (Simon et al., 2010).

Micro satellite alleles were separated by the running the reaction on a 6 per cent denaturing polyacramide gel. The 10bp DNA ladder was used as a size reference. The alleles were visualized after silver staining. Arlequin 3 (Excoffiel et al., 2005) Genalex 6.1 and Darwin 5 software were used for the estimation of molecular diversity. 


\section{Results and Discussion}

Twenty seven genotypes belonging to Narcissus spp. were studied with the help of eleven micro satellites markers, of these twenty seven genotypes fourteen genotypes belonged to Narcissus pseudonarcissus, three belonged Narcissus Tazetta, two belonged to Narcissus jonquilla, two to Narcissus papyraceus and last one to Narcissus poeticus. Similarly matrix among twenty seven genotypes of daffodils based on DNA amplification using SSR markers was obtained using Jaccard's similarly coefficient. The perusal of data recorded that the similarly coefficient ranged between 0.05 and 0.98 respectively. Cluster analysis was conducted on the taxonomic distance matrix with the unweighted pair group method based arithmetic average (UPGMA) and dendrogram was generated (Fig. 1). Dendrogram showed a single cluster at 0.4 per cent of similarity coefficient and at 0.5 per cent similarity two clusters. (Cluster I and II) were found cluster II consists of two genotypes and rest of the genotypes were accommodated in cluster I. At 10 per cent similarity coefficient cluster I was further divided into sub cluster $I_{a 1}$ and $I_{a 2}$. The $I_{a 1}$ consist of 19 genotypes whereas sub cluster $\mathrm{I}_{\mathrm{a} 2}$ consist of 5 genotypes. The sub cluster $\mathrm{I}_{\mathrm{a} 1}$ was cub divided at 17 per cent similarity into two sub cluster $\mathrm{I}_{\mathrm{a} 11}$ and $\mathrm{I}_{\mathrm{a} 12}$.

The analysis of molecular variance was performed using the ARLEQUIN software (Excoffier et al., 2005). The perusal of data (Table 2) regarding the result of analysis of molecular variance (AMOVA) suggested that the large proportion of genetic variation was attributed among individuals across populations $(94.89 \%)$ and small proportion of the total molecular variability existed among the population $(5.11 \%)$. Estimates of the expected heterozygosity $\left(\mathrm{H}_{\mathrm{e}}\right)$ of the different subpopulations has been revealed in (Table
3). The perusal data shows that the population consisting of Narcissus incomparabilis, the highest expected heterozygosity has been shown by the marker $A_{131}(0.73)$ followed by $\mathrm{B}_{109}$ (0.60) and $\mathrm{A}_{5}(0.52)$ respectively. The highest expected heterozygosity $\left(\mathrm{H}_{\mathrm{e}}\right)$ for population 2 (Narcissus pseudonarcissus) was depicted by locus $\mathrm{A}_{131}(0.60)$ followed by $\mathrm{A}_{5}$ $(0.48)$ and $\mathrm{B}_{109} \quad(0.41)$ respectively. In population 3 (Narcissus tazetta) locus $\mathrm{A}_{5}$ revealed highest the (0.50) followed by A131 (0.40), $\mathrm{A}_{109}$ (0.38). Similarly in population 4, 5 and 6 (Narcissus jonquilla, Narcissus papyraceus and Narcissus poeticus) $\mathrm{A}_{5}$ showed $\mathrm{H}_{\mathrm{e}}$ of $0.44, \quad 0.31$ and 0.20 respectively.

The perusal of data (Table 4) depicting number of alleles, observed heterozygosity $\left(\mathrm{H}_{\mathrm{e}}\right)$ and Hardy Weinberg Equillibrum (HWE) revealed that locus $A_{109}$ and $B_{112}$ revealed highest number of alleles which is 10 , it was followed by locus $\mathrm{A}_{5}(9), \mathrm{B}_{104}(8), \mathrm{B}_{7}$ and $\mathrm{A}_{134}$ (7 alleles each) regarding the observed heterozygosity $\left(\mathrm{H}_{0}\right)$ locus $\mathrm{A}_{5}$ recorded highest $\left(\mathrm{H}_{\mathrm{o}}\right)$ (0.68) followed by $\mathrm{B}_{104}(0.60), \mathrm{A}_{116}$ $(0.40)$. The Hardy Weinberg Equillbrum revealed that expect for lolos $\mathrm{B}_{104}$ all other HWE values departed significantly from HWE.

The molecular marker analysis was carried out with the help of eleven SSR primers against 27 genotypes selected from each of the subpopulation species i.e. Narcissus pseudonarcissus, Narcissus incomparibilis, Narcissus tazetta, Narcissus papyraceus, Narcissus jonquilla and Narcissus poeticus.

The AMOVA depicted 94.89 per cent variation within population of Narcissus whereas 5.11 per cent variation among population. Various workers while working on the Narcissus crop using different molecular techniques have revealed same results (Calling et al., 2010; Barret et al., 
2004). Simon et al.,(2010) while working on Narcissus papyraceus using SSR markers revealed that the heterozygosity within population upto 91 per cent while as Medrano and Herrera (2008) while using horizontal starch Gel electrophoresis and screening allozyme variability at 19 loci of Narcissus longispathus revealed that at species level the percentage of the polymorphic loci was 68 per cent. The high level of genetic variation within population could be explained due to the relatively high genetic diversity of small population of the species in comparison to that found in short lived endangered plant species, as the number of generation since the fragmentation occurred was probably low (Oostermeijer and DcKnegt, 2004; Nybom, 2009; Aguilar et al., 2008).

Plate.1 Representative Gel Pictures depicting diversity at microsatellite loci across Narcissus spp.

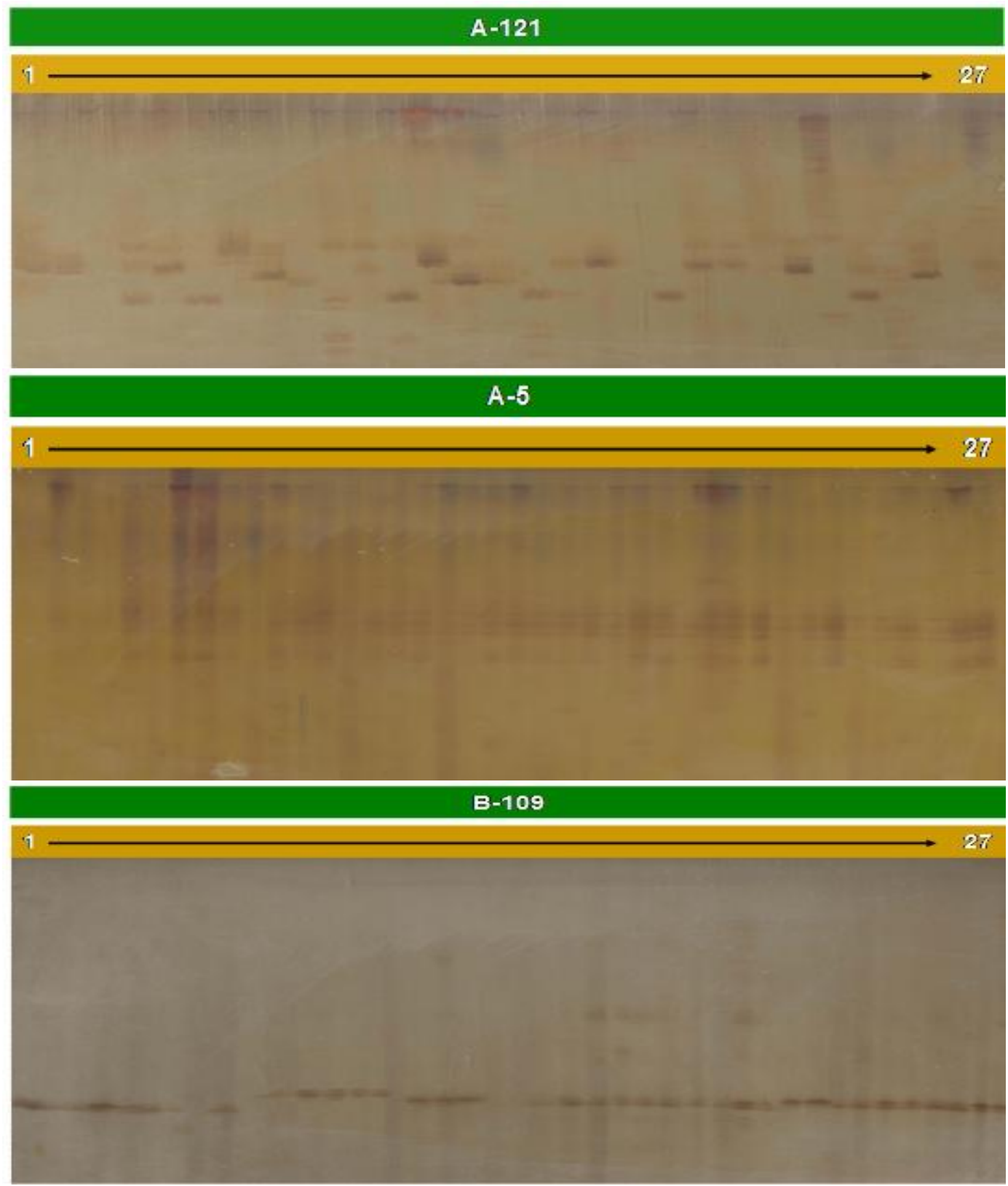


Fig.1 UPGMA based dendrogram showing molecular diversity in daffodils using SSR primers under temperate conditions of Kashmir

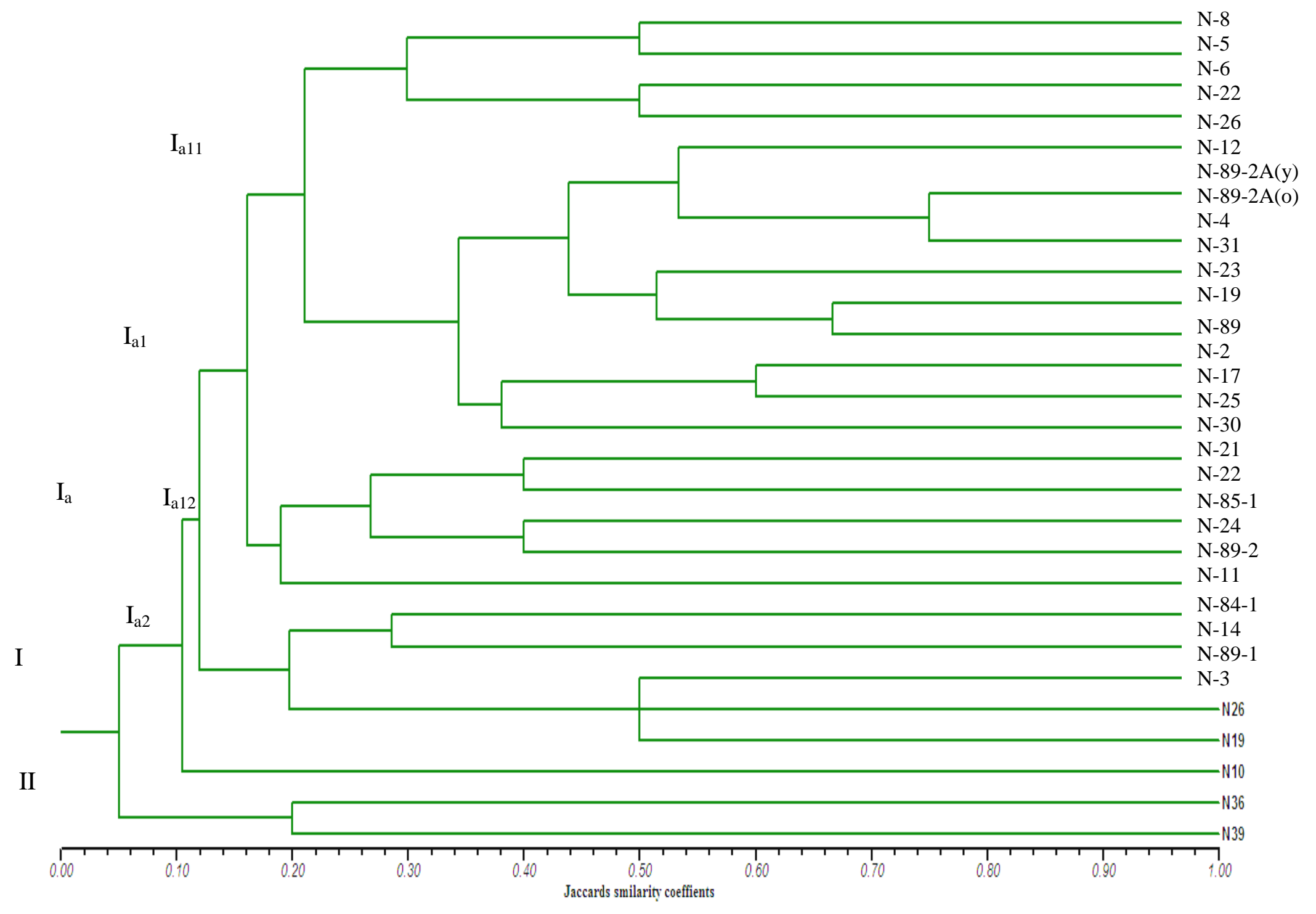


Table.1 Characteristics of 11 microsatellite loci of daffodils used in present study. Gene Bank Accession numbers (below loci names), repeat motifs, forward $(F)$ and reverse $(R)$ primer sequences, allele size ranges and optimal annealing temperatures $\left(\mathrm{T}_{\mathrm{a}}\right)$ are given

\begin{tabular}{|c|c|c|c|c|c|c|}
\hline $\begin{array}{c}\text { Locus } \\
\text { (Gene Bank } \\
\text { Accession No.) }\end{array}$ & $\begin{array}{l}\text { Repeat } \\
\text { motif }\end{array}$ & & Primer sequence & $\mathrm{bp}$ & $\begin{array}{l}\text { Product } \\
\text { size (bp) }\end{array}$ & $\mathrm{T}_{\mathrm{a}}$ \\
\hline \multirow[t]{2}{*}{ A5 (GU271106) } & \multirow{2}{*}{$\mathrm{AC}_{23}$} & $\mathrm{~F}$ & GGACGATTCCAATATGAATTG & 22 & \multirow[t]{2}{*}{$238-298$} & \multirow[t]{2}{*}{58} \\
\hline & & $\mathrm{R}$ & TATGCACACCTGGTATGTCAAG & 22 & & \\
\hline \multirow[t]{2}{*}{ A109 (GU271107) } & \multirow[t]{2}{*}{$\mathrm{TA}_{10} \mathrm{CA}_{14}$} & $\mathrm{~F}$ & GATTGTCAACAAGCATGATATG & 22 & \multirow[t]{2}{*}{$100-132$} & \multirow[t]{2}{*}{57} \\
\hline & & $\mathrm{R}$ & ATGTCGAGTGGATATGGTTATG & 22 & & \\
\hline \multirow[t]{2}{*}{ A116 (GU271108) } & \multirow[t]{2}{*}{$\mathrm{CA}_{26}$} & $\mathrm{~F}$ & GCCATGTTTTATGCCTGA & 18 & \multirow[t]{2}{*}{$262-316$} & \multirow[t]{2}{*}{58} \\
\hline & & $\mathrm{R}$ & ATCCTCACCGGAATCAAC & 18 & & \\
\hline \multirow[t]{2}{*}{ A121 (GU271109) } & \multirow{2}{*}{$\mathrm{GT}_{27}$} & $\mathrm{~F}$ & GGGAGGACCCTAAATCAAGTA & 21 & \multirow[t]{2}{*}{$156-202$} & \multirow[t]{2}{*}{58} \\
\hline & & $\mathrm{R}$ & GCCTAATAAAGCTGCTCCC & 21 & & \\
\hline \multirow[t]{2}{*}{ A131 (GU271110) } & \multirow[t]{2}{*}{$\mathrm{GT}_{11}$} & $\mathrm{~F}$ & AGCTCTCTGTGTGTGTTTCAC & 21 & \multirow[t]{2}{*}{$119-129$} & \multirow[t]{2}{*}{58} \\
\hline & & $\mathrm{R}$ & GGTGACCGTGTCAATTACAC & 20 & & \\
\hline \multirow[t]{2}{*}{ A134 (GU271111) } & \multirow[t]{2}{*}{$\mathrm{GT}_{22}$} & $\mathrm{~F}$ & ACCTCGCTTATGGGTGAG & 18 & \multirow[t]{2}{*}{$276-306$} & \multirow[t]{2}{*}{58} \\
\hline & & $\mathrm{R}$ & ATTTGATACTCGTGGATGGATA & 22 & & \\
\hline \multirow[t]{2}{*}{ B7 (GU271112) } & \multirow[t]{2}{*}{$\mathrm{A}_{15}$} & $\mathrm{~F}$ & AACCTTGTCTCCTCTCTATG & 21 & \multirow[t]{2}{*}{$136-184$} & \multirow[t]{2}{*}{57} \\
\hline & & $\mathrm{R}$ & TTCТСССТСТСТСТTСАТТTC & 21 & & \\
\hline \multirow[t]{2}{*}{ B104 (GU271113) } & \multirow[t]{2}{*}{$\mathrm{GA}_{16}$} & $\mathrm{~F}$ & CTGCTACACCATTAGAGACACC & 22 & \multirow[t]{2}{*}{$156-176$} & \multirow[t]{2}{*}{59} \\
\hline & & $\mathrm{R}$ & ACATCCACTGGTAACAAATCTG & 22 & & \\
\hline \multirow[t]{2}{*}{ B109 (GU271114) } & \multirow[t]{2}{*}{$\mathrm{TC}_{10}$} & $\mathrm{~F}$ & TTCCAACAAGATAACGAACCT & 21 & $179-191$ & 58 \\
\hline & & $\mathrm{R}$ & AAACCGAACCTACACTAAGAGG & 22 & & \\
\hline B112 (GU271115) & $\mathrm{TC}_{18}$ & $\mathrm{~F}$ & CCATTCGACCACACCTACCT & 20 & $286-332$ & 59 \\
\hline & & $\mathrm{R}$ & CCAAGCTCCAAATCTTCGTC & 20 & & \\
\hline B131 (GU271116) & $\mathrm{GA}_{24}$ & $\mathrm{~F}$ & AAACCCACCTTCAAACGA & 18 & $162-186$ & 59 \\
\hline & & $\mathbf{R}$ & TGGAAACTTGTGCCCATAC & 19 & & \\
\hline
\end{tabular}

Address of Gene Bank - Genetic Identification Services

(www.genetic-id-services.com) $\mathrm{F}=$ Forward primer; $\mathrm{R}=$ Reverse primer

Table.2 Analysis of molecular variance (AMOVA) of different characters in daffodils genotypes under temperate conditions of Kashmir

\begin{tabular}{|l|c|c|c|c|c|}
\hline Source of variation & $\begin{array}{c}\text { Degrees of } \\
\text { freedom (d.f.) }\end{array}$ & $\begin{array}{c}\text { Sum of squares } \\
\text { (ss) }\end{array}$ & $\begin{array}{l}\text { Variance } \\
\text { components }\end{array}$ & $\begin{array}{l}\text { Percentage } \\
\text { of variation }\end{array}$ & FST \\
\hline Among populations & 5 & 13.186 & $0.1497 \mathrm{Va}$ & 5.11 & \\
\hline Within populations & 21 & 61.111 & $2.777 \mathrm{Vb}$ & 94.89 & 0.0511 \\
\hline Total & 26 & 74.296 & 2.927 & & 0.0511 \\
\hline
\end{tabular}


Table.3 Estimates of expected heterozygosity $\left(\mathrm{H}_{\mathrm{e}}\right)$ for the sub-populations of Narcissus species

\begin{tabular}{|c|c|c|c|c|c|c|c|c|}
\hline \multirow[t]{2}{*}{ Locus } & \multirow{2}{*}{$\begin{array}{l}\text { Repeat } \\
\text { motif }\end{array}$} & \multicolumn{7}{|c|}{ Expected Heterozygosity } \\
\hline & & $\begin{array}{c}\text { Population 1 } \\
\text { (N.Incomparibilis) }\end{array}$ & $\begin{array}{c}\text { Population } 2 \\
\text { (N. Pseudonarcissus) }\end{array}$ & $\begin{array}{c}\text { Pop.3 } \\
\text { (N.Tazetta) }\end{array}$ & $\begin{array}{c}\text { Pop.4 } \\
\text { (N. Jonquilla) }\end{array}$ & $\begin{array}{c}\text { Pop.5 } \\
\text { (N. Papyraceus) }\end{array}$ & $\begin{array}{c}\text { Pop. } 6 \\
\text { (N. Poeticus) }\end{array}$ & $\begin{array}{l}\text { Total } \\
(\mathrm{He})\end{array}$ \\
\hline A5 & Ac23 & 0.52 & 0.48 & 0.50 & 0.44 & 0.31 & 0.10 & 0.71 \\
\hline A109 & $\mathrm{Ta}_{10} \mathrm{CA} 14$ & 0.47 & 0.40 & 0.38 & 0.30 & 0.0 & 0.0 & 0.48 \\
\hline A116 & $\mathrm{CA}_{26}$ & 0.20 & 0.39 & 0.0 & 0.0 & 0.0 & 0.0 & 0.43 \\
\hline A121 & $\mathrm{GT}_{27}$ & 0.50 & 0.40 & 0.20 & 0.0 & 0.0 & 0.0 & 0.50 \\
\hline A131 & $\mathrm{GT}_{11}$ & 0.73 & 0.60 & 0.40 & 0.40 & 0.0 & 0.0 & 0.64 \\
\hline A134 & $\mathrm{GT}_{22}$ & 0.45 & 0.36 & 0.10 & 0.0 & 0.0 & 0.0 & 0.59 \\
\hline B7 & $\mathrm{GA}_{15}$ & 0.40 & 0.40 & 0.29 & 0.20 & 0.20 & 0.0 & 0.57 \\
\hline B104 & $\mathrm{GA}_{16}$ & 0.47 & 0.29 & 0.20 & 0.20 & 0.11 & 0.11 & 0.70 \\
\hline B109 & $\mathrm{TC}_{10}$ & 0.60 & 0.41 & 0.30 & 0.30 & 0.0 & 0.00 & 0.64 \\
\hline B112 & $\mathrm{TC}_{18}$ & 0.29 & 0.20 & 0.11 & 0.11 & 0.0 & 0.0 & 0.48 \\
\hline B131 & $\mathrm{GA}_{24}$ & 0.20 & 0.18 & 0.40 & 0.36 & 0.0 & 0.0 & 0.58 \\
\hline Mean & & 0.43 & 0.37 & 0.26 & 0.21 & 0.05 & 0.01 & 0.56 \\
\hline
\end{tabular}


Table.4 Results of Number of Alleles (A), observed heterozygosity $\left(\mathrm{H}_{\mathrm{o}}\right)$, gene diversity $\left(\mathrm{H}_{\mathrm{e}}\right)$ and $\mathrm{P}$-value for the Hardy- Weinberg (HWE)

\begin{tabular}{|c|c|c|c|c|}
\hline Locus & $\mathrm{A}$ & $\mathrm{H}_{0}$ & $\mathrm{H}_{\mathrm{e}}$ & HWE \\
\hline $\mathbf{A}_{\mathbf{5}}$ & 9 & 0.66 & 0.71 & $\mathbf{0 . 0 1 6}^{*}$ \\
\hline $\mathbf{A}_{109}$ & 10 & 0.30 & 0.48 & $\mathbf{0 . 0 0}$ \\
\hline $\mathbf{A}_{116}$ & 7 & 0.40 & 0.43 & $\mathbf{0 . 0 1 3}^{*}$ \\
\hline $\mathbf{A}_{121}$ & 7 & 0.16 & 0.50 & $\mathbf{0 . 0 0 3}^{*}$ \\
\hline $\mathbf{A}_{131}$ & 5 & 0.33 & 0.64 & $\mathbf{0 . 3 3 4}^{*}$ \\
\hline $\mathbf{A}_{134}$ & 7 & 0.06 & 0.59 & $\mathbf{0 . 0 0 0}$ \\
\hline $\mathbf{B}_{\mathbf{7}}$ & 7 & 0.27 & 0.57 & $\mathbf{0 . 0 0 2} *$ \\
\hline $\mathbf{B}_{104}$ & 8 & 0.60 & 0.70 & $\mathbf{0 . 1 8 2}$ \\
\hline $\mathbf{B}_{109}$ & 5 & 0.33 & 0.64 & $\mathbf{0 . 0 0 4}$ \\
\hline $\mathbf{B}_{112}$ & 10 & 0.31 & 0.49 & $\mathbf{0 . 0 0}$ \\
\hline $\mathbf{B}_{\mathbf{1 3 1}}$ & $\mathbf{4}$ & $\mathbf{0 . 2 0}$ & $\mathbf{0 . 5 7}$ & $\mathbf{0 . 0 3} *$ \\
\hline
\end{tabular}

*Significant departure from HWE

Fragmented population of long lived plant species may conserve a high level genetic diversity for a long time if the plant are survivors of formerly large population (Kahman and Poschold, 2000; Luijtens et al., 2000). Similarly because of its long generation time the relatively high genetic variation of most populations of Narcissus could reflect the genetic diversity of formally much larger population, this could explain the weak relation between genetic variability and current population size. Jaccard's similarity data a UPGMA based dendrogram was established showing molecular diversity in daffodils, same procedure was also utilized in daffodils by Tucci et al., (2004) and Nunez et al., (2003). High proportion of polymorphic loci and mean number of allele per locus occurring within population suggest that these have not experienced severe or long lasting population bottlenecks causing loss of genetic diversity. On the other hand the predominantly low level of inbreeding and predominantly outcrossing matting system any of which could also contribute to maintain the higher levels of genetic variation observed. Ecological and demographic characteristics of the species, such as higher habitat stability, low population turnover or extended persistence of individual genotypes through clonal reproduction are also likely to favour the maintenance of high level of genetic variations (Barret et al., 2004). Although numerous studies have reported positive relationship between population size and within population genetic diversity (Van Rossum et al., 2004; Prentice et al., 2006; Honnay et al., 2007).

This study provides insight into the geographic structure of genetic diversity that reflects the evolutionary history of the species and also reveals that the daffodils maintain a definite population structure indicating efficient gene flow among these populations resulting high within group divergence of individuals. Therefore, this warrants that selection and crossing should be based upon the useful genetic variation across the species.

\section{Acknowledgement}

Authors are thankful to Division of Floriculture, S.K. University of Agricultural Sciences and Technology of Kashmir, Shalimar Srinagar (J\&K) for extended research and financial support. 


\section{References}

Aguilar, R., Quesada, M., Ashworth, L., Herrerias-Diego, Y. and Lobo, J. 2008. Genetic Consequences of habitat fragmentation in plant populations: susceptible signals in plant traits and methodological approaches. Molecular Ecology 17: 5177-5188.

Barrett, S.C.H., Cole, W.W. and Herrera, C.M. 2004. Mating patterns and genetic diversity in the wild daffodil Narcissus longispathus

(Amaryllidaceae). Hereditary 92: 459-465.

Brickel, C. 1996. Narcissus. In: The Royal Horticultural Society A-Z Encyclopaedia of Garden Plant. Dorling Kinderslay Press, London, pp. 689-696.

Colling, G., Hemmer, P., Bonniot, A., Hermant, S. and Matthies, D. 2010. Population genetic structure of wild daffodils (Narcissus pseudonarcissus L.) at different spatial scales. Plant System Evolution 111: 287-299.

Excoffier, L., Laval, G. and Schneider, S. 2005. ArlequinVer3.0: an integrated software package for population genetics data analysis. Evolutionary Bioinformatics Online 1: 47-50.

Field, D. and Wills, C. 1996. Long, polymorphic microsattelites in simple organisms; Proceeding R. Soc. London Ser. 263: 209-221.

Gur-Arie, R., Cohen, C.J., Eitan, Y., Shelef, L., Hallerman, E.M. and Kashi, Y. 2000. Simple sequence repeats in Escherichia coli abundance, distribution, Composition and polymorphism. Genome Research10: 62-71.

Honnay, O., Adriaens, D., Coert, E., Jacquemyn, H. and Roldan-Ruiz, I. 2007. Genetic diversity within and between remnant populations of endangered calcareous grass-land plant
Globularia bisnagarica L. Conservation Genetics8: 298-303.

Ji, Z. and Meerow, A.W. 2000. Narcissus. In: Flora of China (Eds. Z.Y. Wu and P.H. Raven), vol. 24 (Fagellariaceae through Marantoceae). Science Press, Beijing and Missouri Botanical Garden Press, St. Louis.

Kahman, S. and Poschlod, P. 2000. Population size, plant performance and genetic variation in the rare plant Arniamontana L. In the Rhon, Germany. Basic Applied Ecology 1: 4351.

Luijten, S.H., Dierick, A., Oostermeijer, J.G.B., Raijmann, L.E.L. and Dennijs, H.C.M. 2000. Population size, genetic variation and reproductive success in a rapidly declining, self-incompatible perennial (Arnica montana) in the Netherlands. Conservation Biology 14: 1776-1787.

Maroof, M.A., Saliman, K.M., Jorgensen, R.A. and Anand, R.W. 1984. Ribosomal DNA spacer length polymorphism in Barley: species diversity, chromosomal location and population dynamics. PNAS91: 5466-5470.

Medrano, M. and Herrera, C.M. 2008. Geographical structuring of Genetic diversity across the whole distribution range of Narcissus longispathus, a Habitat specialist. Mediterranean Narrow Endemic Annals of Botany102: 183-194.

Nunez, D.R., Castro, C.O.D., Ruiz, S.R. and Ariza, F.A. 2003. The origin of cultivation and wild ancestors of daffodils (Narcissus subgenus Ajax) (Amaryllidaceae) from an analysis of early illustrations. Scientia Horticulture 98: 307-330.

Nybom, H. 2004. Comparison of different nuclear DNA markers for estimating intraspecific genetic diversity in plants. Molecular Ecology 13: 1143-1155. 
Oostermeijer, J.G.B. and De-Knegt, B. 2004. Genetic population structure of the wild pollinated, dioecious shrub Juniperuscommunis in fragmented Dutch heathlands. Plant Species Biology 19: 175-184.

Perez-Barrales, R., Vargas, P. and Arroyo, J. 2006. New evidence for the Darwinian hypothesis of heterostyly: Breeding systems and pollinations in Narcissus sect. Apodanthi. The New Phytologist 171:553-567.

Prentice, H.C., Lonn, M., Rosquist, G., Ihse, M. and Kindstorm, M. 2006 Gene diversity in a fragmented population of Briza media grassland continuity in a landscape context. Journal of Ecology94: 87-97.

Simon, V.I., Pico, F.X. and Arroya, J. 2010. New microsatellite loci for Narcissus papyraceus (Amarillydaceae) and cross amplification in other congeneric species. American Journal of Botany pp. 10-13.

Spaulding, D.D. and Barger, T.W. 2014. Key to the wild daffodils (Narcissus, Amaryllidaceae) of Alabama and adjacent states. Phytoneuron 82: 1-10.

Straley, G.B. and Utech, F.H. 2002.
Narcissus. In: Flora of North America (Editorial Committee Flora of North America), North of Mexico, vol. 26, Oxford University Press, New York and London.

Tucci, G.F., Winfield, M.O., Amoto, G.F., Gregor, C., Trombetta, B. and DeDominicus, R.I. 2004. Genetic diversity in Narcissus poeticus $\mathrm{L}$. and $N$. radiiflorus Salisb. (Amaryllidaceae) in two different populations. AFLP and Karyological Studies.

Van-Belkum, A., Scherer, S., Van Alphen, L. and Verbrugh, H. 1998. Short Sequence DNA repeats in prokaryotic genomes. Microbiol. Mol. Biol. Rev. 62: 275-293.

Van-Rossum, F., Campos de Sousa, S. and Triest, L. 2004. Genetic consequences of habitat fragmentation in an agricultural landscape on the Common Primulaveris and Comparison with its rare congener; $P$. vulgaris. Conservation Genetics, 5: 231-245.

Weising, K., Nybom, H., Wolff, K. and Kahl, G. 2005. DNA finger printing in plants: principles, methods, and applications. $2^{\text {nd }}$ edition: CRC Press, Taylor \& Francis group; Boca Raton FL-USA.

\section{How to cite this article:}

Rehman, S.I., M.Q. Sheikh, Z.A. Bhat and Khan, M.H. 2019. Genetic Diversity Analysis Based on SSR Markers in Daffodils (Narcissus). Int.J.Curr.Microbiol.App.Sci. 8(05): 2418-2427. doi: https://doi.org/10.20546/ijcmas.2019.805.286 